\title{
Molecular data reveal the hybrid nature of an introduced population of banded newts (Ommatotriton) in Spain
}

\author{
Isolde van Riemsdijk ${ }^{1}\left[\right.$ (D) Laurens van Nieuwenhuize ${ }^{1} \cdot$ Iñigo Martínez-Solano $^{2}$ • \\ Jan W. Arntzen ${ }^{1}$ Ben Wielstra ${ }^{3,4}$
}

Received: 31 May 2017 / Accepted: 7 August 2017 / Published online: 16 August 2017

(c) The Author(s) 2017. This article is an open access publication

\begin{abstract}
The three species of banded newt (genus Ommatotriton) are endemic to the Near East. Recently an introduced banded newt population was discovered in Catalonia, Spain. To determine the species involved and the geographical source, we genotyped 11 individuals for one mitochondrial and two nuclear genetic markers, and compared the observed haplotypes to a range-wide phylogeography of Ommatotriton. All haplotypes identified in Spain are identical to haplotypes known from the native range. The mitochondrial haplotypes derive from $O$. ophryticus and were originally recorded in northeast Turkey. The nuclear haplotypes reveal that all individuals are genetically admixed between $O$. ophryticus and $O$. nesterovi. While the geographical resolution for the nuclear markers is low, the source of the $O$. nesterovi ancestry must be Turkey, as this species is a Turkish endemic. Species distribution models suggest a large potential distribution for the two Ommatotriton species, extending over northern Iberia and southern France. The ecology of hybrids can differ substantially from
\end{abstract}

Electronic supplementary material The online version of this article (doi:10.1007/s10592-017-1004-0) contains supplementary material, which is available to authorized users.

Isolde van Riemsdijk

isolde.vanriemsdijk@naturalis.nl

1 Naturalis Biodiversity Center, P.O. Box 9517, 2300 RA Leiden, The Netherlands

2 Departamento de Biodiversidad y Biología Evolutiva, Museo Nacional de Ciencias Naturales, c/ José Gutiérrez Abascal 2, 28006 Madrid, Spain

3 Department of Ecology and Evolutionary Biology, University of California, Los Angeles, CA 90095, USA

4 Department of Animal and Plant Sciences, University of Sheffield, Sheffield S10 2TN, UK that of the parent species, making the impact of the Spanish hybrid banded newt population difficult to predict.

Keywords Amphibia - Exotic species - Genotyping · Hybridisation · Invasive species $\cdot$ Species distribution modelling

\section{Introduction}

Human activities are causing a worldwide mass extinction of amphibians (Wake and Vredenburg 2008). Next to habitat destruction, the most important anthropogenic factor causing species extinctions is the introduction of exotic species (Sax and Gaines 2003). While many exotic species disappear quickly after introduction, some occasionally become invasive and threaten local wildlife (Pimentel et al. 2001). Competition with and predation by exotic taxa can cause major declines in native taxa (Kats and Ferrer 2003). Introduced species may also carry alien pathogens against which native species do not have an adequate immune response (Martel et al. 2014). Moreover, introduced species may threaten the genetic integrity of natives by hybridisation (Fitzpatrick and Shaffer 2007; Meilink et al. 2015).

In May 2011, an introduced population of banded newts (Ommatotriton sp.), a genus endemic to the Near East (c. $3000 \mathrm{~km}$ eastwards), was discovered in two adjacent ponds near Lleida in Catalonia, Spain (Fontelles et al. 2011, Fig. 1). The newts were found in an area with many ponds and watering holes for cattle. Efforts to eradicate the population are underway, including the direct removal of adults and larvae, and desiccation of ponds (Fontelles et al. 2011; D. Martínez, pers. comm). In October 2016, after the peak of emergence of juveniles, few metamorphic individuals were 


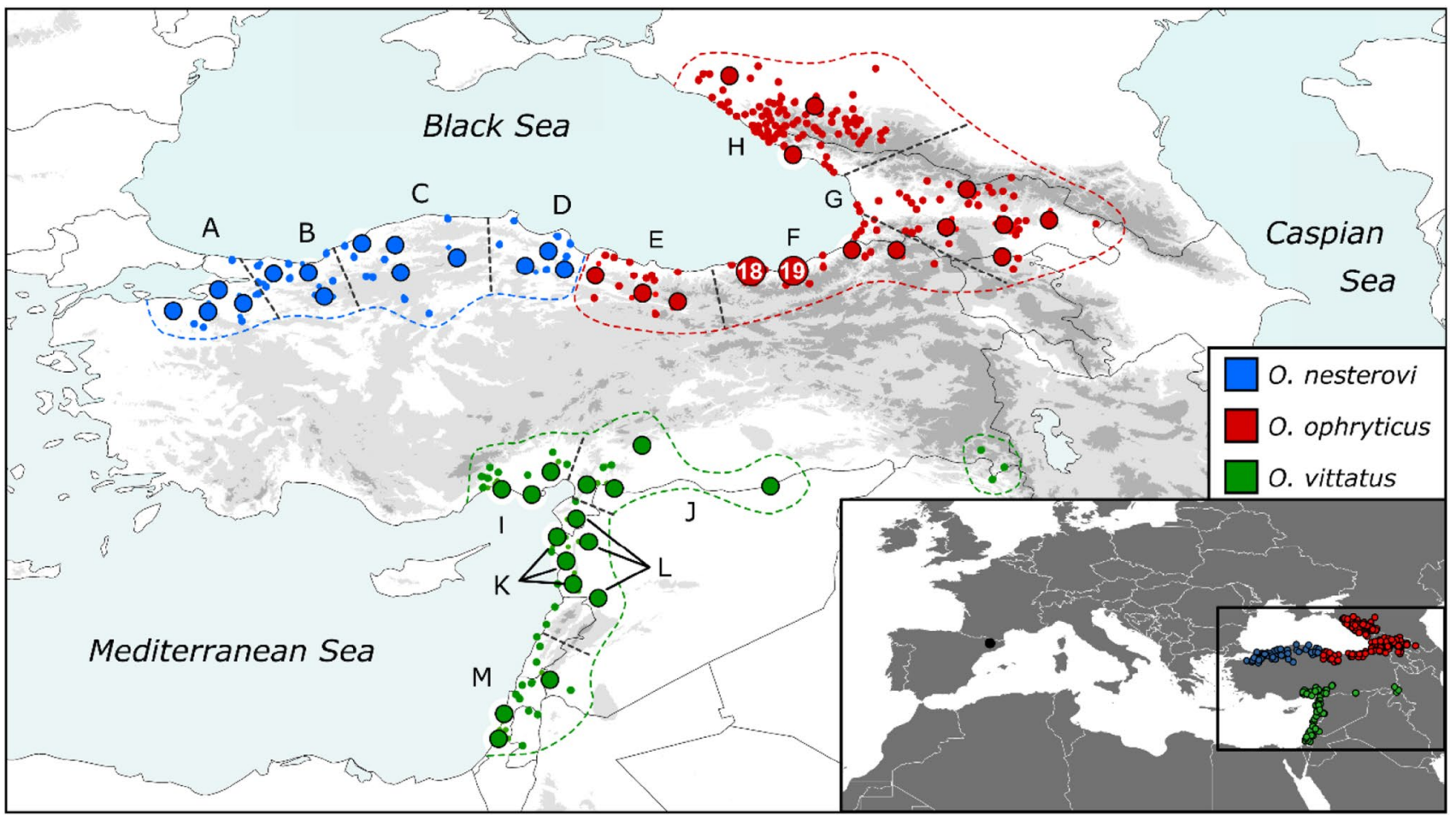

Fig. 1 Distribution map of the three banded newt Ommatotriton species, native to the Near East. The inset shows the position of the introduced population in Spain (black dot). On the main map, large dots are populations for which genetic data are available and small dots are additional locations used for species distribution modelling

recorded in the vicinity of the ponds, suggesting a successful population reduction.

The genus Ommatotriton comprises three species: $O$. nesterovi, $O$. ophryticus and $O$. vittatus. The number of ribbearing vertebrae (NRBV) can be used to distinguish $O$. ophryticus $(\mathrm{NRBV}=13)$ from the other two $(\mathrm{NRBV}=12$ : Arntzen and Olgun 2000; Litvinchuk et al. 2005; Kutrup and Bülbül 2011). Based on X-rays of a single individual with NRBV $=13$, the Spanish population was identified as O. ophryticus (Fontelles et al. 2011). However, NRBV is known to be environmentally plastic in salamanders (Arntzen et al. 2015). Furthermore, pictures of Spanish banded newts show features reminiscent of $O$. nesterovi, in particular the lateral white band that continues from the front limbs up to the eye and is interrupted by large blue specks on the tail (B. Wielstra, unpublished data).

Considering the uncertainty regarding specific identity and hence the geographic origin of the introduced banded newt population, we genotyped 11 Spanish individuals for one mitochondrial and two nuclear markers and compared the results to a range-wide Ommatotriton phylogeography (van Riemsdijk et al. 2017). We also used species distribution modelling to investigate the potential of the Spanish banded newts to spread over Iberia. (van Riemsdijk et al. 2017). Dots are coloured according to species. Letters correspond to phylogeographic clades in Fig. 2. Spanish mitochondrial haplotypes were previously reported from localities 18 and 19. (Color figure online)

\section{Materials and methods}

Tail and toe tips from 11 Spanish Ommatotriton individuals were collected with permission from the Servicio de Fauna y Flora, Generalitat de Catalunya, Spain. Samples are stored in the Museo Nacional de Ciencias Naturales Tissue and DNA Collection in Madrid, Spain (Online Resources 1). DNA was extracted with the Qiagen DNeasy Blood \& Tissue Kit. Fragments of one mitochondrial (COI, 658 bp) and two nuclear markers (KIAA, $600 \mathrm{bp}$ and SACS, $624 \mathrm{bp}$ ), all nuclear markers for which reference data from the natural range are available, were amplified following van Riemsdijk et al. (2017). Sanger sequencing was done commercially at BaseClear B.V., Leiden, The Netherlands. Sequences were edited in Sequencher 4.10.1 (Gene Codes Corporation, MI USA) and nuclear alleles were phased with the PHASE 2.1 algorithm (Stephens and Donnelly 2003) in DnaSP 5 (Librado and Rozas 2009). Sequences were combined with the dataset of van Riemsdijk et al. (2017) in Mesquite (Maddison and Maddison 2015) and collapsed into unique haplotypes (Online Resources 1). For the nuclear markers, haplotype networks were built using PopArt 1.7 (Bandelt et al. 1999; Leigh et al. 2016). Species distribution models for $O$. ophryticus and $O$. nesterovi, based on bioclimatic values and 
presented in van Riemsdijk et al. (2017), and an additional model combining distribution data for both species were projected onto current climate layers of northern Iberia, to approximate the suitable area in the introduced range and the invasive potential of the exotic population.

\section{Results}

All mitochondrial and nuclear haplotypes observed in the Spanish population were identical to haplotypes from the native range (van Riemsdijk et al. 2017). The two mitochondrial haplotypes found in the Spanish population were identical to O. ophryticus haplotypes from the Trabzon Province in north-eastern Turkey (Figs. 1, 2a, localities 18 and 19 in van Riemsdijk et al. 2017). The Bayesian phylogenetic tree for COI in Fig. $2 \mathrm{a}$ is adapted from van Riemsdijk
Fig. 2 Haplotypes identified in introduced Spanish banded newt Ommatotriton samples in the context of a range-wide phylogeography. A Bayesian phylogeny for COI (a). Asterisks indicate posterior probability values $>0.95$ and letters correspond to clades indicated in Fig. 1. Haplotype networks of KIAA (b) and SACS (c). Haplotypes are coloured according to the species of origin and Spanish ones are shown as purple pie slices. (D) Overview of all haplotypes found in Spain. Haplotype codes correspond to van Riemsdijk et al. (2017). (Color figure online)

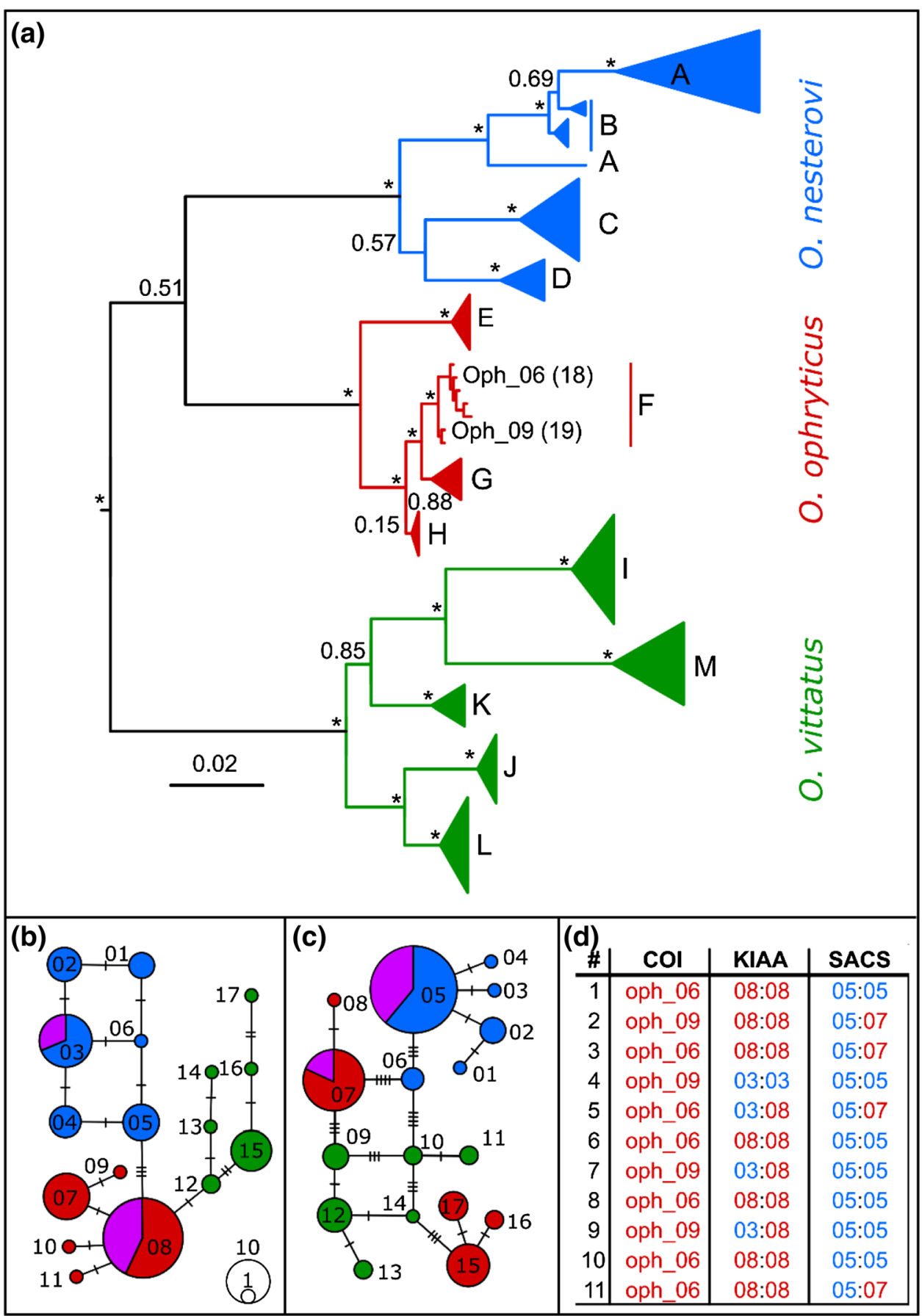


et al. (2017). For both nuclear markers two haplotypes were recovered, one previously found in $O$. nesterovi and one in O. ophryticus (Fig. 2b, c, d). All Spanish individuals show ancestry of both species. Linking nuclear haplotypes to particular native localities is impossible as both nuclear markers show little intraspecific phylogeographic structure. Species distribution models suggest that conditions at the Spanish introduction site are unfavourable for $O$. nesterovi, but favourable for O. ophryticus (Fig. 3). A 'hybrid model' based on distribution data for both species suggests that conditions in and around the introduction site are more suitable for admixed newts than for the individual parental species.

\section{Discussion and conclusions}

Mitochondrial DNA suggests that the introduced banded newt population in Spain concerns O. ophryticus, in line with the number of rib-bearing vertebrae (Fontelles et al. 2011). However, the nuclear markers show all individuals are genetically admixed between $O$. ophryticus and a second species, $O$. nesterovi, the presence of which was hypothesized based on pictures. Species identification based on mitochondrial data alone has proven, once again, to be misleading (Vences et al. 2005). As all sampled newts are hybrids, the individuals initially introduced in Spain must have been either a mix of pure individuals of $O$. nesterovi and $O$. ophryticus, or hybrids themselves. This is the first evidence that hybrids between these two species are viable.

While the lack of geographic resolution for the nuclear haplotypes prevents us to identify a detailed geographical origin of the source for $O$. nesterovi ancestry, the country of origin is clear as this species is endemic to north-west Turkey. While for $O$. ophryticus the nuclear markers also lack geographic resolution, the mitochondrial marker pinpoints the origin of $O$. ophryticus ancestry to north-east Turkey. Considering that the contact zone between $O$. ophryticus and $O$. nesterovi is positioned c. $400 \mathrm{~km}$ to the west of the inferred region of origin of $O$. ophryticus, the Spanish population cannot derive from natural hybrids. Rather, taking into account that $O$. ophryticus and $O$. nesterovi have only recently been recognized (Litvinchuk et al. 2005; Bülbül and Kutrup 2013; van Riemsdijk et al. 2017), the two species likely interbred in the pet trade.

The main impacts of invasive species on natives are competition, predation, transfer of alien pathogens, and hybridisation. The introduced banded newts are likely to compete for resources with native newts and prey on eggs and larvae of native amphibians to some degree (Borkin et al. 2003). A chytrid fungus, Batrachochytrium salamandrivorans, which has proven highly lethal to European Salamandridae, was introduced via the salamander pet trade (Martel et al. 2014).
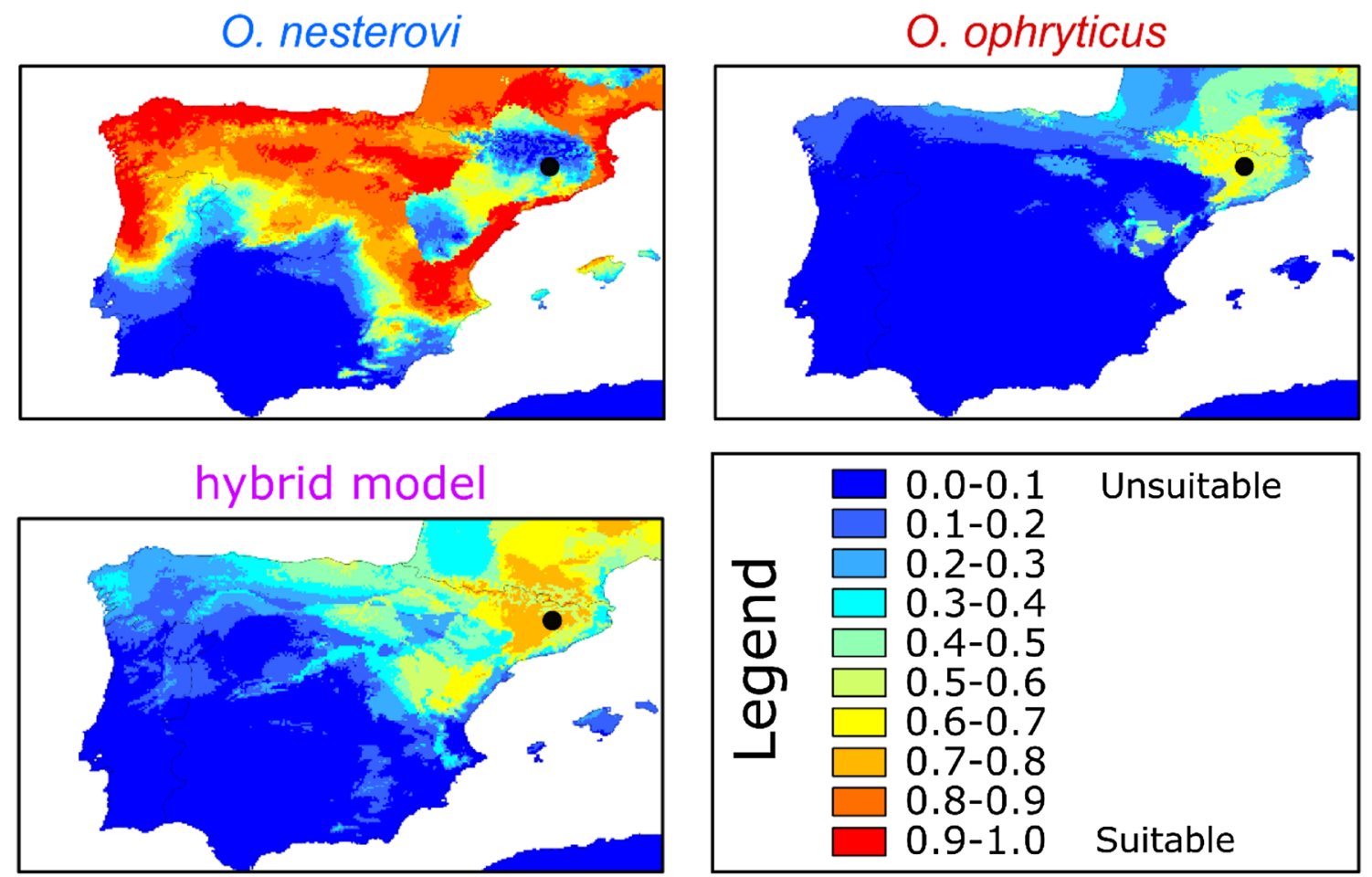

Fig. 3 Species distribution models for two banded newt species, O. nesterovi (upper left) and O. ophryticus (upper right), and a 'hybrid model' based on distribution data for both species (bottom left), projected on the Iberian Peninsula. The black dot indicates the introduction site 
While no elevated amphibian mortality has been reported at the introduction site, monitoring should include screening for chytrid fungus and other pathogens (four introduced alpine newts, Ichthyosaura alpestris, in Catalonia were infected with a Ranavirus, see Martínez-Silvestre et al. 2017). Hybridisation with native newt species, like Triturus marmoratus or Lissotriton helveticus seems a negligible risk, as Ommatotriton is not closely related (Arntzen et al. 2015).

The intermingled genomes in the hybrid banded newt population make it hard to approximate the actual niche (Canestrelli et al. 2016). Hybridisation is known to potentially speed up the evolutionary process, leading to increased potential to adapt to new conditions (Allendorf et al. 2001; Dittrich-Reed and Fitzpatrick 2013). Species distribution models highlight the potential of the introduced population to colonize northern Iberia and adjacent France. However, expansion beyond the introduction site might be slowed down because of a low density of suitable breeding ponds surrounding it and an extirpation effort in place (D. Martínez, pers. comm.). However, a contained introduced population could still negatively affect the native amphibian community locally.

The hybrid nature of the Spanish introduced banded newt population makes their impact on native species harder to predict. When the genomes of hybridising species are complementary, the resulting offspring may have a higher fitness than either of the parent species, resulting in a population of 'hopeful monsters' (Fitzpatrick and Shaffer 2007; DittrichReed and Fitzpatrick 2013). Tangible proof of this theory was found for Ambystoma salamanders in California, where hybrid larvae between a native and an invasive species show a higher survival rate than either parent species (Fitzpatrick and Shaffer 2007).

Considering the unpredictability of hybrids, we urge the relevant authorities to treat the biological control of the Spanish introduced banded newt population with caution. The efficiency of current measures such as the continued removal of individuals and pond drying should be closely monitored. Even if complete eradication might prove impossible, these measures are likely to reduce the negative effects of the exotic hybrid Ommatotriton population in Spain.

Acknowledgements D. Herrero, D. Martínez, F. Stănescu, D. Székely and A. Tarragó helped collect or provided samples. The $\mathrm{PhD}$ position of IvR is supported by the 'Nederlandse organisatie voor Wetenschappelijk Onderzoek' (NWO Open Programme 824.14.014). This project has received funding from the European Union's Horizon 2020 research and innovation programme under the Marie SkłodowskaCurie Grant Agreement No. 655487.

\section{Compliance with ethical standards}

Ethical approval Collection of tissue samples for molecular analyses was authorized by the Servicio de Fauna y Flora, Generalitat de Catalunya, Spain.
Open Access This article is distributed under the terms of the Creative Commons Attribution 4.0 International License (http://creativecommons.org/licenses/by/4.0/), which permits unrestricted use, distribution, and reproduction in any medium, provided you give appropriate credit to the original author(s) and the source, provide a link to the Creative Commons license, and indicate if changes were made.

\section{References}

Allendorf FW, Leary RF, Spruell P, Wenburg JK (2001) The problems with hybrids: setting conservation guidelines. Trends Ecol Evol 16:613-622. doi:10.1016/S0169-5347(01)02290-X

Arntzen JW, Olgun K (2000) Taxonomy of the banded newt, Triturus vittatus: morphological and allozyme data. Amphibia-Reptilia 21:155-168

Arntzen JW, Beukema W, Galis F, Ivanović A (2015) Vertebral number is highly evolvable in salamanders and newts (family Salamandridae) and variably associated with climatic parameters. Contrib Zool 84:85-113

Bandelt HJ, Forster P, Rohl A (1999) Median-joining networks for inferring intraspecific phylogenies. Mol Biol Evol 16:37-48. doi:10.1093/oxfordjournals.molbev.a026036

Borkin LJ, Litvinchuk SN, Zuiderwijk A (2003) Triturus vittatus (Gray, 1835) - Bandmolch. In: Grossenbacher K, Thiesmeier B (eds) Handbuch der Reptilien und Amphibien Europas. Aula-Verlag, Wiebelsheim, pp 555-605

Bülbül U, Kutrup B (2013) Morphological and genetic variations of Ommatotriton in Turkey. Anim Biol 63:297-312. doi:10.1163/15707563-00002413

Canestrelli D, Porretta D, Lowe WH et al (2016) The tangled evolutionary legacies of range expansion and hybridization. Trends Ecol Evol. doi:10.1016/j.tree.2016.06.010

Dittrich-Reed DR, Fitzpatrick BM (2013) Transgressive hybrids as hopeful monsters. Evol Biol 40:310-315. doi:10.1007/ s11692-012-9209-0

Fitzpatrick BM, Shaffer HB (2007) Hybrid vigor between native and introduced salamanders raises new challenges for conservation. Proc Natl Acad Sci 104:15793-15798. doi:10.1073/ pnas.0704791104

Fontelles F, Guixé D, Martínez-Silvestre A et al (2011) Hallada una población introducida de Ommatotriton ophryticus en el Prepirineo catalán. Boletín la Asoc Herpetológica Española 22:153-156

Kats LB, Ferrer RP (2003) Alien predators and amphibian declines: Review of two decades of science and the transition to conservation. Divers Distrib 9:99-110. doi:10.1046/j.1472-4642.2003.00013.x

Kutrup B, Bülbül U (2011) Comparison of skeletal muscle protein bands and trunk vertebrae count between Ommatotriton ophryticus nesterovi and $O$. o. ophryticus populations in Turkey. Turk $\mathrm{J}$ Zool 35:579-584. doi:10.3906/zoo-0904-6

Leigh J, Bryant D, Steel M (2016) PopArt 1.7

Librado P, Rozas J (2009) DnaSP v5: a software for comprehensive analysis of DNA polymorphism data. Bioinformatics 25:14511452. doi:10.1093/bioinformatics/btp 187

Litvinchuk SN, Zuiderwijk A, Borkin LJ, Rosanov JM (2005) Taxonomic status of Triturus vittatus (Amphibia: Salamandridae) in western Turkey: trunk vertebrae count, genome size and allozyme data. Amphibia-Reptilia 26:305-323

Maddison WP, Maddison DR (2015) Mesquite: a modular system for evolutionary analysis. Evolution 62:1103-1118

Martel A, Blooi M, Adriaensen C et al (2014) Recent introduction of a chytrid fungus endangers Western Palearctic salamanders. Science 346:630-631. doi:10.1126/science. 1258268 
Martínez-Silvestre A, Montori A, Oromi N et al (2017) Detection of a Ranavirus in introduced newts in Catalonia (NE Spain). Herpetol Notes 10:23-26

Meilink WRM, Arntzen JW, van Delft JJCW, Wielstra B (2015) Genetic pollution of a threatened native crested newt species through hybridization with an invasive congener in the Netherlands. Biol Conserv 184:145-153. doi:10.1016/j.biocon.2015.01.022

Pimentel D, McNair S, Janecka J et al (2001) Economic and environmental threats of alien plant, animal, and microbe invasions. Agric Ecosyst Environ 84:1-20. doi:10.1016/S0167-8809(00)00178-X

Sax DF, Gaines SD (2003) Species diversity: from global decreases to local increases. Trends Ecol Evol 18:561-566. doi:10.1016/ S0169-5347(03)00224-6

Stephens M, Donnelly P (2003) A comparison of Bayesian methods for haplotype reconstruction from population genotype data. Am J Hum Genet 73:1162-1169. doi:10.1086/379378 van Riemsdijk I, Arntzen JW, Bogaerts S, Franzen M, Litvinchuk SN, Olgun K, Wielstra B (2017) The Near East as a cradle of biodiversity: a phylogeography of banded newts (genus Ommatotriton) reveals extensive inter- and intraspecific genetic differentiation. Mol Phylogenet Evol 114:73-81. doi:10.1016/j. ympev.2017.05.028

Vences M, Thomas M, Bonett RM, Vieites DR (2005) Deciphering amphibian diversity through DNA barcoding: chances and challenges. Philos Trans R Soc Lond B 360:1859-1868. doi:10.1098/ rstb.2005.1717

Wake DB, Vredenburg VT (2008) Are we in the midst of the sixth mass extinction? A view from the world of amphibians. PNAS 105:11466-11473. doi:10.1073/pnas.0801921105 